\title{
Learning Tools Development to Improve Students Critical Thinking Skills on the Topics of Plant Structures in Technology through Guided Discovery Learning Models
}

Eko Wahyuningsih", Muhammad Zaini, Suryajaya

Master of Teacher Training In Natural Science Education, Lambung Mangkurat University Indonesia

\author{
DOI: $10.36348 /$ jaep.2020.v04i08.001 $\quad$ | Received: 19.08 .2020 | Accepted: 26.08 .2020 | Published: 30.08 .2020 \\ *Corresponding author: Eko Wahyuningsih
}

\section{Abstract}

The PISA report illustrates Indonesia's ranking in terms of critical thinking among students is still below the average of other countries from year to year. Critical thinking skills are very important skills that are trained in students to be able to compete in various fields. The success of achieving the learning objectives lies in the ability of the teacher to carry out the learning process and the success of the learning process lies in the learning device as a standard so it is necessary to develop the learning device. The purpose of this study is to produce learning tools that train critical thinking skills of junior high school students on plant structure material and their use in technology using a guided discovery learning model that is valid, practical and effective. This study uses the Tessmer model, which consists of: 1) self evaluation; 2) expert review; 3) one-to-one; 4) small group; 5) field tests and products produced in the form of complete learning tools, namely: syllabus, teaching materials, student worksheets, student critical thinking skills assessment sheet, teacher activity evaluation sheet, student activity evaluation sheet. The subjects of the study were $8^{\text {th }}$ grade students at SMPN 1 Angsana. The results of this study indicate that the device passed the test based on validity, practicality, and effectiveness. Another finding is that students are considered capable of being at a good level of critical thinking.

Keywords: learning tools, critical thinking, guided discovery learning.

Copyright @ 2020: This is an open-access article distributed under the terms of the Creative Commons Attribution license which permits unrestricted use, distribution, and reproduction in any medium for non-commercial use (NonCommercial, or CC-BY-NC) provided the original author and sources are credited.

\section{INTRODUCTION}

The education world is currently experiencing various challenges including having to be able to score students who are able to compete in this globalization era. The 2013 curriculum aims to prepare Indonesian people to have the ability to live as individuals and citizens who are faithful, productive, creative, innovative and effective and able to contribute to social life, nation and state and world civilization (Permendikbud No. 64 of 2013). Therefore there is a need for curriculum development so that the learning process is more targeted and meaningful.

The latest results of PISA 2018, shows the ability of Indonesian students is ranked 72 out of 77 countries. With the ability of science down from 403 to 396 points. This fact shows that there must be improvement in the learning process, especially how to improve students' thinking levels.

Critical thinking is one of the skills in sorting out which is the value of the many ideas or making consideration of a decision [1]. According to Falsaime [2], there are five indicators in critical thinking namely identifying problems, defining problems clearly, exploring problems and possible solutions, evaluating their application and identifying understanding with existing knowledge. According to the results of Sanjaya's research [3] showed that $76.6 \%$ of student learning outcomes were influenced by teacher performance with details: the ability of teaching teachers to contribute $32.43 \%$, mastery of subject matter contributed $32.38 \%$ and teacher attitudes towards learning contributed $8.60 \%$. From these data shows that there are things that must be improved in terms of the quality of learning. One way to improve the quality of learning is to develop devices.

Teacher competence is very important in building students' critical skills especially in designing a learning scenario. A teacher before making learning tools must be able to analyze and develop learning strategies that link teaching material and the real environment, so that when students follow the learning process in class will be more meaningful. According to 
Artistiana [4] that the development of devices is a process to develop students' potential towards a better direction. In the implementation process, the device developed was not only able to make students solve ordinary problems, but also helped improve their thinking level.

The nature of learning science has three components, namely components of the product, process and attitude. Science as a product means a collection of facts, concepts, principles and laws about natural phenomena. Science as a process is a series of stages of structured and systematic learning that is carried out to find concepts, principles, laws and natural phenomena. While IPA as an attitude is expected to form scientific characters such as curiosity, honesty, objective, thinking, open, conscientious, determined, brave and polite. So it is clear that what is desired in science learning students are able to behave and be able to show the character they have [5].

One model of learning in order to achieve these objectives is guided learning. Because the guiding principle of implementing curriculum in learning is to use a contextual approach to the strengthening process by using a scientific (scientific) approach and authentic assessment that uses the assessment principle of part of learning. Scientific approaches in learning can be applied using the Discovery/Inquiri learning model (Permendikbud No. 58 of 2014 concerning Basic and Secondary Education Process Standards).

According to J. Bruner, guided discovery learning (GDL) is a learning model developed based on a cognitive view of learning and constructivist principles. In the process guided discovery learning encourages students to learn independently on their own. Students learn through active involvement with concepts and principles, and the teacher encourages students to gain experience and carry out activities that enable them to find principles for themselves.

According to Herdian [6] discovery learning method is a teaching method that focuses on student activities in learning. In the learning process with this method, the teacher only acts as a guide and facilitator who direct students to find concepts, propositions, procedures, algorithms and the like. Teaching and learning activities are expected to be able to involve teachers and students to the maximum. If students are actively involved in discovering mathematical patterns and structures, they will understand concepts and theorems better, remember longer and be able to apply them to other situations.

The environment is an ideal learning media for students in understanding a material, where in making discoveries a media that is easily digested and understood by students is needed. Based on data from BALITBANG Kemdikbud in 2014 that the competence of "the role of living things" and competence of "the role of humans on the environment" are material that has fluctuative absorption. Therefore the material structure and function of plant tissue and its use in technology taught using the GDL model makes it possible to improve understanding of these competencies as a prerequisite while training students' critical thinking skills.

Previous research has shown good results about being able to improve the quality of thinking. Balim [7] suggested that student learning outcomes improved due to the application of guided discovery learning learning models. Klahr \& Nigam, [8] also found that the quality of students' scientific thinking using guided discovery learning models. Yuliani \& Saragih [9] also found those students' critical thinking skills and understanding of concepts improved by using guided discovery learning.

Learning science in the Tanah Bumbu district high school, at the beginning of the 2019/2020 school year already used the 2013 curriculum but the curriculum messages had not been implemented perfectly. From the review conducted during the implementation of subject teacher deliberations (MGMP) on existing learning tools, it is obtained data that teachers are more cognitive training not yet developed how to train high-level thinking. And researchers conducted an analysis of the results of tests that introduced the question of critical thinking skills to 147 students only reached $22 \%$ who had the skills to think critically.

\section{RESEARCH METHODS}

Research on the development of this learning tool uses Tessmer's five-step formative evaluation [10]. These five steps consist of self-evaluation, expert review, individual trial stages, field trials in small groups, and trials in large groups. The trial design is guided by the formative evaluation flow design. Through formative evaluation the validity, practicality, and effectiveness are obtained. Validity is obtained from consultation with experts on the content of learning tools by conducting Forum Group Discussion (FGD). Practicality is obtained in accordance with established criteria, that is, according to the students' mindset, students understand the context provided, are easy to read, and do not cause diverse interpretations. Effectiveness is obtained through small group trials and field trials. Small group trials are used to determine the effectiveness of expectations derived from assessments of students including worksheet work, Learning Outcomes Test (THB) and assessment of students' critical thinking skills.

The trial subjects used a total sample of 47 students in $7^{\text {th }}$ grades at SMPN 1 Angsana. Section expert review through 3 experts in the field of natural science education. Peer teachers are also involved in 
monitoring/observing the research process for evaluation. Data collection techniques are done through observation, documentation, and tests. The data generated in the form of data validity, data on the level of readability of textbooks and worksheets, data on the implementation of lesson plans, data on student process skills, and data on student learning outcomes.

\section{RESEARCH RESULTS AND DISCUSSION \\ Learning Tools Validation}

Expert validation is done after the device design is made, in the form of syllabus, lesson plans, teaching materials and student worksheets. Following are the results of device validation:

Table-1: Observation Results on the Implementation of Teacher Activities

\begin{tabular}{|c|l|c|c|c|c|c|}
\hline \multirow{2}{*}{ No } & \multirow{2}{*}{ Validated Indicators/Aspects } & \multicolumn{3}{|c|}{ Scores of validator } & \multirow{2}{*}{ Modus } & \multirow{2}{*}{ Criteria } \\
\cline { 3 - 5 } & & $\mathbf{V 1}$ & $\mathbf{V 2}$ & $\mathbf{V 3}$ & & \\
\hline 1 & Syllabus & 4 & 4 & 4 & 4 & Very Valid \\
\hline 2 & Learning Implementation Plan (RPP) & 4 & 4 & 4 & 4 & Very Valid \\
\hline 3 & Teaching materials & 4 & 4 & 4 & 4 & Very Valid \\
\hline 4 & Student worksheet (LKPD) & 4 & 4 & 4 & 4 & Very Valid \\
\hline 5 & Cognitive Assessment Sheet & 4 & 4 & 4 & 4 & Very Valid \\
\hline 6 & Psychomotor Assessment Sheet & 4 & 4 & 4 & 4 & Very Valid \\
\hline 7 & Affective Assessment Sheet & 4 & 4 & 4 & 4 & Very Valid \\
\hline 8 & Critical Thinking Assessment Sheet & 4 & 4 & 4 & 4 & Very Valid \\
\hline
\end{tabular}

Learning tools are valid based on assessment 1) syllabus, 2) lesson plans, 3) teaching materials, 4) LKPD, 5) assessment sheets. This research has resulted in a prototype of a valid, practical and effective RPP tool. Nieveen [11] as quoted by Mafumiko [12] explains the prototype means all products that are designed before getting the final product or duplicated and fully implemented in real conditions.

The lesson plan is valid based on syllabus indicators, lesson plans, LKPD, teaching materials and assessment sheets. The device is said to be valid if the assessment of all aspects validated is good [13]. A valid RPP tool if the components are in accordance with the validity indicator of the RPP tool [14]. Validation is one of the criteria that determines the quality of a product [15]. a. In the validity of the learning device individual tests are conducted on students

b. Individual test (one-to-one) aims to identify grammatical errors, spelling, punctuation, unclear instructions, incorrect capital letters, and missing graphics $[10,26]$.

c. Individual tests complete the evaluation information from the learner's point of view.

d. Students as users think that LKPD, teaching materials and evaluation tools are good. Riduwan [17] states the opinions of students at least good categories.

\section{Practicality of Learning Tools}

The practicality test was carried out at the $8^{\text {th }}$ grade level with a total of 12 students whose results were to see the feasibility of learning and the response back from the students.

Table-2: Lesson Plan Implementation

\begin{tabular}{|c|l|l|l|l|}
\hline Meeting & Activity & Implementation & Percentage & Information \\
\hline \multirow{4}{*}{1} & Opening & 24 & 100 & All done \\
\cline { 2 - 5 } & Main & 24 & 100 & All done \\
\cline { 2 - 5 } & Closing & 18 & 75 & Not informing the next assignment \\
\hline \multirow{3}{*}{2} & Opening & 24 & 100 & All done \\
\cline { 2 - 5 } & Main & 24 & 100 & All done \\
\cline { 2 - 5 } & Closing & 24 & 100 & All done \\
\hline \multirow{3}{*}{3} & Opening & 24 & 100 & 85.66 \\
\cline { 2 - 5 } & Main & 21 & 87 & Less guide in observing and making hypotheses \\
\cline { 2 - 5 } & Closing & 14 & 70 & Not giving awards, PR \\
\hline \multirow{4}{*}{4} & Opening & 24 & 100 & 95.66 \\
\cline { 2 - 5 } & Main & 21 & 87 & Not asking students to analyze the problems in the LKPD \\
\cline { 2 - 5 } & Closing & 16 & 100 & All done \\
\hline \multirow{3}{*}{5} & Opening & 24 & 100 & 88.66 \\
\cline { 2 - 5 } & Main & 27 & 96 & Less guide the presentation \\
\cline { 2 - 5 } & \multirow{2}{*}{ Closing } & 14 & 70 & $\begin{array}{l}\text { Does not give appreciation, and does not facilitate } \\
\text { reflection }\end{array}$ \\
\hline
\end{tabular}


Table-3: Student Responses

\begin{tabular}{|c|c|c|c|c|c|c|}
\hline \multirow{2}{*}{ No } & \multirow{2}{*}{ Observed Aspects } & \multicolumn{5}{|c|}{ Answer Choices } \\
\hline & & SA & $\mathbf{A}$ & $\mathbf{N}$ & D & SD \\
\hline 1. & $\begin{array}{l}\text { Learning tools with Guided discovery leaning model make students } \\
\text { very interested and happy to learn about plant structure material and } \\
\text { its use in technology. }\end{array}$ & 7 & 5 & 0 & 0 & 0 \\
\hline 2. & $\begin{array}{l}\text { Learning tools with Guided discovery leaning models motivate } \\
\text { students to improve critical thinking skills in studying plant structure } \\
\text { material and its use in technology }\end{array}$ & 8 & 4 & 0 & 0 & 0 \\
\hline 3. & $\begin{array}{l}\text { Learning tools with guided discovery leaning models make students } \\
\text { correct the concise errors in plant structure materials and their use in } \\
\text { technology that they understand. }\end{array}$ & 10 & 2 & 0 & 0 & 0 \\
\hline 4. & $\begin{array}{l}\text { Learning tools with guided discovery leaning models can increase } \\
\text { awareness of the importance of protecting the environment in plant } \\
\text { structure material and its use in technology }\end{array}$ & 12 & 0 & 0 & 0 & 0 \\
\hline 5. & $\begin{array}{l}\text { Learning tools with guided discovery leaning models that involve } \\
\text { practical activities and discussions, provide learning experiences to } \\
\text { understand the concept of plant structure material and its use in } \\
\text { technology }\end{array}$ & 8 & 3 & 0 & 0 & 0 \\
\hline 6. & $\begin{array}{l}\text { Learning tools with guided discovery leaning models improve } \\
\text { science process skills with plant structure materials and their use in } \\
\text { technology. }\end{array}$ & 8 & 4 & 0 & 0 & 0 \\
\hline 7. & $\begin{array}{l}\text { Learning activities carried out in small groups on the guided } \\
\text { discovery leaning model enable me to work with friends in groups } \\
\text { and can improve my ability to think critically with plant structure } \\
\text { material and its use in technology }\end{array}$ & 7 & 5 & 0 & 0 & 0 \\
\hline 8. & $\begin{array}{l}\text { Learning activities carried out in small groups on the guided } \\
\text { discovery leaning model make students able to take responsibility } \\
\text { related to plant structure material and its use in technology }\end{array}$ & 6 & 6 & 0 & 0 & 0 \\
\hline 9. & $\begin{array}{l}\text { Learning tools with guided discovery leaning model make students } \\
\text { able to express ideas without any restrictions so as to further } \\
\text { enhance the critical thinking skills that I had before }\end{array}$ & 7 & 4 & 1 & 0 & 0 \\
\hline 10. & $\begin{array}{l}\text { Learning tools with guided discovery leaning models make students } \\
\text { have knowledge of technological ideas inspired by plant structure } \\
\text { materials and their use in technology }\end{array}$ & 11 & 1 & 0 & 0 & 0 \\
\hline
\end{tabular}

Note: SA

$$
\begin{aligned}
& =\text { Strongly Agree } \\
& =\text { Agree } \\
& =\text { Neutral } \\
& =\text { Disagree } \\
& =\text { Strongly Disagree }
\end{aligned}
$$

Learning tools of the research results have been said to be practical, this is supported by research data based on: 1) the implementation of lesson plans by partner teachers; and 2) student responses. Plomp \& Nieveen [18] states that the practicality of devices can be known from the results of observations of the implementation of learning and students' responses to the learning device. The teacher's ability to teach the device in the classroom to classroom management is done by partner teachers in the small group test of preliminary activities, core activities, and closing activities during four meetings which are quite good.

This means that the ability of partner teachers in learning the learning tools using the RPP syntax using guided discovery learning based learning models that have been scenarios implemented is quite well implemented so it can be said that the learning tools developed by researchers are practical. Nur [16] states the learning process can be made very meaningful by giving students the opportunity to discover or implement the learning themselves through a learning plan.

According to Nieveen [11] practical is a tool/material that can be used and is easy for teachers and students to use it. This means that the partner teacher is able to manage the class well because all the learning tools have been studied and understood by the partner teacher before testing the device. The results of this study are supported by studies that have been previously reported. Teachers help students generate questions to guide investigations [19]. Learning using guided discovery learning model can be one way to provide the experience of prospective teachers in the field [20].

Students give a positive response to the learning process with the GDL-based model. Students who agree, this means proving that the use of LKPD, teaching materials and the use of guided discovery learning models have been accepted and liked by 
students. This is in line with the research of Suprihatin \& Hidayah [21] that students give a positive response to the implementation of learning activities because the average student feels happy and motivated through the guided discovery learning learning model. Apriliyana [22] reported that learning devices with guided discovery learning models received positive responses from students. The results of research on students' responses to learning are in accordance with previous research. Schaal [20] says students feel more competent than students in other courses for implementing similar approaches in future teaching.

\section{Effectiveness of Learning Tools}

Table-4: Recapitulation of Cognitive Field Test Results

\begin{tabular}{|l|c|c|}
\hline \multicolumn{1}{|c|}{ Criteria } & Total & Percentage \\
\hline Mastery & 18 & 75 \\
\hline Not Mastery & 6 & 25 \\
\hline
\end{tabular}

Table-5: Results of analysis of students' critical thinking

\begin{tabular}{|l|c|c|}
\hline \multicolumn{1}{|c|}{ Criteria } & Total & Percentage \\
\hline Students who think critically & 24 & 100 \\
\hline $\begin{array}{l}\text { Students who don't think } \\
\text { critically }\end{array}$ & 0 & 0 \\
\hline
\end{tabular}

Learning tools are said to be effective because all indicators have been fulfilled namely 1) product cognitive learning outcomes, and 2) results of critical thinking skills assessment. RPP tools are effective because cognitive learning outcomes have exceeded the established KKM limits. This is due to the items developed that have been declared valid. According to Akbar [23] good test questions are valid, that is, questions that can measure abilities as they are or test results according to the actual situation. Appraisal tools are said to be valid if the tool is able to assess what should be assessed, that is, the objectives measured must be in accordance with the material being assessed and the questions in the appraisal measure aspects as described in basic competencies or indicators [24]. The implementation of RPP tools resulting from effective development is used to train science process skills and strengthen the science learning concept [25]. Guided Discovery learning based RPP devices have a positive effect on student learning outcomes [35-37]. Development of RPP tools based on guided discovery learning can show an increase in student competencies, because the guided discovery learning syntax can accommodate spiritual competence, social, knowledge and skills [26].

Critical thinking skills are very good, previous reports support the results of this study [27-30]. Guided discovery-based learning is positively correlated with students' critical thinking skills [34]. Guided discoverybased learning has a significant positive impact on students' critical thinking skills [31].
Critical thinking skills are needed and should be owned by students [32]. The worksheet of students resulting from the development is effective for growing students' critical thinking skills [29]. Critical thinking skills become one of the effectiveness of learning tools [30]. Students' critical thinking skills include formulating problems, formulating hypotheses, collecting data, analyzing data, and making conclusions on average of good categories [33].

\section{CONCLUSION}

The results of research conducted in general have been able to answer the research objectives. The results of the development and research showed that the learning tools developed were considered appropriate for use. Validity is done using the level of validation of experts (experts and practitioners) represented by three lecturers and two teachers. Based on the results of the validation results, the tools which include syllabus, lesson plans, teaching materials, worksheets, and assessment sheets meet the validity requirements (valid and very valid) based on the results of expert validation. The practicality of the device is seen from the implementation of the lesson plan based on the results of the observer's assessment showing the implementation of learning that took place both from beginning to end of the learning process. Effectiveness is seen from the achievement of learning objectives namely the device is able to be used to train critical thinking skills and students with indicators that is an increasing trend at each meeting. The attitude seen in this study is the character skills and social skills of students. This good trend shows that the tools developed have a good impact on critical thinking skills and students' attitudes during the learning process in class.

The findings of research that have been carried out are that there is a tendency for students' initial level of knowledge to be weak as well as a low understanding of concepts due to their interest in learning and low literacy levels. The facts that the research findings can be overcome with intensive guidance by the teacher. Guidance from the teacher is a very important factor in achieving goals so that students have good critical thinking skills, as well as patience to carry out continuous learning in the same way and allocate enough time because students are not familiar with this way of learning.

\section{REFERENCES}

1. Tawil, M., \& Liliasari. (2013). Berpikir kompleks dan ilmplementasinya dalam pembelajaran IPA. Makassar: Badan Penerbit UNM.

2. Filsaime, D. K. (2008). Menguak Rahasia Berpikir Kritis dan Kreatif. Jakarta: Prestasi Pustakarya.

3. Sanjaya, W. (2006). Strategi Pembelajaran. Jakarta: Kencana Prenada Media Group. 
4. Artistiana, Nenden, R. (2013). Mengenal dan Mempraktekkan Model-Model Pembelajaran di Sekolah. Jakarta Timur: CV. Sahala Adidayatama.

5. Suastra, I.W. (2009). Pembelajaran Sains Terkini: Mendekatkan Siswa dengan Lingkungan Alamiah dan Sosial Budayanya. Singaraja: Universitas Pendidikan Ganesha.

6. Herdian. (2010). Strategi Belajar Mengajar. Bandung: Pustaka Setia.

7. Balim, A. G. (2009). The Effect of Discovery Learning on Students Success and Inquiry Skills. Eurasian Journal of Educational Research. Issue 35, 1-21.

8. Klahr, D., \& Nigam, M. (2004). The Equivalence of Learning Paths in Early Science Instruction: Effects of Direct Instruction and Discovery Learning. Psychological science, 15(10).

9. Yuliani, K., \& Saragih, S. (2015). The Development of Learning Devices Based Guided Discovery Model to Improve Understanding Concept and Critical Thinking Mathematically Ability of Student at Islamic Junior High School of Medan. Journal of Education and Practice, 6(24),116-128.

10. Tessmer. (1998). Planning and Conducting Formative Evaluations. Philadelphia: Kogan Page.

11. Nieveen, N. (1999). Prototype to reach product quality. In van den Akker, J., Branch, R.M., Gustafson, K., Nieveen, N., \& Plomp, T. Design Approaches and Tools in Educational and Training. Dordrecht: Kluwer Academic Publisher.

12. Mafumiko, F. (2006). Micro-scale experimentation as a catalyst for improving the chemistry curriculum in Tanzania. Doctoral thesis, University of Twente, Enschede.

13. Nisa, I. (2012). Pengembangan Perangkat Pembelajaran IPA Terpadu Tipe Connected dengan Topik Peredaran Darah untuk Kelas VIII SMP. Pendidikan Sains, 1(1), 26-38.

14. Dewi, N. K. (2013). Commuter marriage: Ketika berjauhan menjadi sebuah keputusan (When apart into a decision) Jakarta.

15. Akker, J.V.D., Bannan, B., Kelly A.E., Nieveen, N., dan Plomp, T. (2007). An Introduction to Educational Design Research. Proceedings of the seminar conducted at the East China Normal University. Shanghai (PR China). November 23-26.

16. Nur, M. (2013). Pendidikan dan Latihan Pembelajaran Inovatif dan Pengembangan Perangkat Pembelajaran Bermuatan Keterampilan Berpikir dan Perilaku Berkarakter. Kerjasama Program Studi Magister Pendidikan Biologi PPs Unlam dengan Pusat Sains dan Matematika Sekolah (PSMS) Unesa. Universitas Negeri Surabaya. Januari, $17^{\text {th }}-19^{\text {th }} 2013$.

17. Riduwan. (2015). Dasar-Dasar Statistika, Bandung: Alfabeta.

18. Plomp, T., \& Nieveen, N. (2007). Formative Evaluation in Educational Design Research. In
Plomp, T., \& Nieveen, N. (Eds.). An Intruction to Educational. Natherland: SLO.

19. McBride, J.W., Bhatti, M.I., Hannan, M.A \& Feinberg, M. (2012). Using an Inquiry Approach to Teach Science to Secondary School Science Teachers. Procedia - Social And Behavioral Sciences, 46(2012) 2327-2333.

20. Schaal, S., Matt, M., \& Grübmeyer, S. (2012). Mobile Learning and Biodiversity-Bridging the Gap between Outdoor and Inquiry Learning in PreService Science Teacher education. Procedia Social and Behavioral Sciences, 46, 2327-2333.

21. Suprihatin, E., \& Hidayah, Y. (2014). Penerapan Model Pembelajaran InkuiriTerbimbing Pada Konsep Pencemaran Lingkuangan dalam Melatih Keterampilan Menyelesaikan Masalah Siswa. Jurnal Ilmiah Kependidikan, 9(2): 11-24. ISSN: 0216-7433. Banjarmasin: STKIP PGRI Banjarmasin.

22. Apriliyana, U. (2012). Pengembangan Perangkat Pembelajaran BerbasisInkuiri pada Materi Pencemaran Lingkungan dalam Upaya Melatih Keterampilan Berpikir Kritis Siswa Kelas X SMA. Thesis (not published). Surabaya: Universitas Negeri Surabaya.

23. Akbar, Sa'dun. (2013). Instrumen Perangkat Pembelajaran. Bandung: Rosdakarya.

24. Ratumanan, G.T., \& Laurens, T. (2011). Evaluasi Hasil Belajar pada Tingkat Satuan Pendidikan. Surabaya: UNESA University Press.

25. Rinarta, I. N., Yuanita, L., \& Widodo, W. (2014). Pengembangan Perangkat Pembelajaran Model Inkuiri untuk Melatihkan Keterampilan Proses Sains dan Penguasaan Konsep Siswa SMP. Jurnal Pendidikan Fisika. Vol. 2(2): 70-88.

26. Henykartikasari, T., Indriwati. E. S., \& Prabaningtyas, S. (2015). Pengembangan Perangkat RPP Berbasis Inkuiri pada Mata Pelajaran Biologi Materi Jamur untuk Meningkatkan Kompetensi Siswa Kelas X SMA Brawijaya Smart School Malang. Jurnal Ilmu Hayati Universitas Negeri Malang, 1(1): 1-11.

27. Rachmawati, Dwita., \& Rohaeti, E. (2018). Pengaruh Model Pembelajaran Sains, Teknologi, Dan Masyarakat Terhadap Kemampuan Berpikir Kritis Dan Motivasi Belajar Peserta Didik. Jurnal Pendidikan Matematika dan Sains, VI(1): 29-39.

28. Sutama, I N., Arnyana, I. B. P., \& Swasta, I. B. J. (2014). Pengaruh Model Pembelajaran Inkuiri Terhadap Pada Pelajaran Biologi Kelas XI IPA SMA Negeri 2 Amlapura Singaraja Indonesia. EJournal Program Pascasarjana Universitas Pendidikan Ganesha. 4.

29. Kurniawati, W., \& Atmojo, S. E. (2015). Pengembangan lembar kerja berbasis inkuiri terintegrasi kelompok mata pelajaran perekat bangsa untuk menumbuhkan kemampuan berpikir dan karakter ilmiah siswa. Elementary School: Jurnal Pendidikan dan Pembelajaran ke-SD-an, 2(1): 47-53. 
30. Zaini, M., \& Supiati. (2017). Developing Learning Device on Environment Pollution Topic in Senior High School. Article number 31887-TSS. The Social Sciences, Medwell Journal Scientific Research Publishing Company. 12(12): 2269-2276.

31. Duran, M., \& Dökme, İ. (2016). The effect of the inquiry-based learning approach on student's critical-thinking skills. Eurasia Journal of Mathematics, Science \& Technology Education, 12(12), 2887-2908.

32. Beaumont, J. (2010). A Sequence of CriticalThinking Tasks. TESOL Journal, 1(4), 122.

33. Zaini, M. (2016). Guided Inquiry Based Learning on the Concept of Ecosystem toward Learning Outcomes and Critical Thinking Skills of High School Students. IOSR Journal of Research \& Method in Education (IOSR-JRME), e-ISSN: 2320-7388, p-ISSN: 2320-737X 6th. ed. 6(VIII): $50-55$.
34. Rahmawati, D., Nugroho, S. E., \& Putra, N. M. D. (2014). Penerapan model pembelajaran kooperatif tipe numbered head together berbasis eksperimen untuk meningkatkan keterampilan proses sains siswa SMP. UPEJ Unnes Physics Education Journal, 3(1).

35. Rosmalina, Y., Permaesih, D., Emawati, F., Christiani, R., Moeloek, D., \& Herman, S. (2013). Faktor-faktor yang berhubungan dengan tingkat kesegaran jasmani lansia laki-laki tidak anemia. Nutrition and Food Research,26(1), 156130.

36. Sumiyadi, K. I. S. Masturi. (2015). Pengembangan Perangkat Pembelajaran Ipa Berbasis Inkuiri Dan Berwawasan Konservasi. Journal of Innovative Science Education Vl, 4, 1-8.

37. Febriani, C. A. (2016). Faktor-faktor yang berhubungan dengan deteksi dini kanker leher rahim di Kecamatan Gisting Kabupaten Tanggamus Lampung. Jurnal kesehatan, 7(2), 228237. 